\title{
Enrich Schematization in Children: Play as The Tool for Cognitive Development
}

\author{
Vidya Bhagat ${ }^{1}$, Mainul Haque ${ }^{2}$, Kamarudin Jaalam ${ }^{3}$ \\ ${ }^{1}$ Faculty of Medicine, Universiti Sultan Zainal Abidin, Medical Campus, Jalan Sultan Mahmud, 20400 Kuala Terengganu, Terengganu, Malaysia. \\ ${ }^{2}$ Unit of Pharmacology, Faculty of Medicine and Defence Health, Universiti Pertahanan Nasional Malaysia (National Defence University of Malaysia), Kem \\ Sungai Besi, 57000 Kuala Lumpur, Malaysia. \\ ${ }^{3}$ School of Medical Sciences, University Sains Malaysia, Health Campus, 16150 Kubang Kurian, Kelantan, Malaysia.
}

\begin{tabular}{lll}
\hline ARTICLE INFO & & ABSTRACT \\
\cline { 1 - 1 } $\begin{array}{l}\text { Article history: } \\
\text { Received on: } 12 / 03 / 2018\end{array}$ & $\begin{array}{l}\text { Cognitive development gets toned by the improved external environment that can facilitate developing children. The } \\
\text { play basing Piagetian cognitive development found to be a useful tool in enriching cognitive development in children. } \\
\text { Accepted on: } 25 / 06 / 2018\end{array}$ & $\begin{array}{l}\text { Parents and teachers can use naturalistic play therapy provided them with basic knowledge about Piagetian cognitive } \\
\text { development and related play in the early stage of development. Thus, they can use their own pattern of play with age- } \\
\text { Available online: } 30 / 07 / 2018\end{array}$ \\
$\begin{array}{l}\text { Kelated suitability that can enrich schemas in children and promote schematization process and cognitive development. } \\
\text { Schematization, Play, }\end{array}$ & $\begin{array}{l}\text { The purpose of the article is to communicate newly created play therapy supporting cognitive development. Further to } \\
\text { understand the role of play in Piaget's schematization process. This article is useful in conceptualizing the perspective } \\
\text { of cognitive development and its association with an interactive play in enriching schemas in the early development } \\
\text { of children. }\end{array}$ \\
\hline
\end{tabular}

\section{INTRODUCTION}

Cognitive development takes place throughout the developmental stages of one's life. It is a process of constructing various thought processes that involved in remembering, problem-solving, and decision-making, from childhood through adolescence to adulthood. Children progress through a series of four critical stages of cognitive development (Gruber and Voneche, 1995). Dr Jean Piaget was a Swiss psychologist was the first to make a systematic study of cognitive development of child and explains how a child constructs a mental model of the world (McLeod, 2018). Indeed, this stage to stage changes that take place in the developmental stages is an integral part of Piagetian cognitive development (Gruber and Voneche, 1995). Throughout the development, children react to their environment and actively involved in learning about their environment. The child's acquired

"Corresponding Author

Mainul Haque, Unit of Pharmacology, Faculty of Medicine and Defence

Health, Universiti Pertahanan Nasional Malaysia (National Defence

University of Malaysia), Kem Sungai Besi, 57000 Kuala Lumpur,

Malaysia.E-mail:runurono@gmail.com;mainul@upnm.edu.my knowledge gets composed in the schemas through schematization process. That start from developing basic units of instruction that are an organized unit of past experiences and serve as a basis for understanding new ones (Gruber and Voneche, 1995).

Introduction of age-related play can expand the schematization process in children. It has been learned from the literature that age-related play in children take place through the different developmental stages is helpful in enriching cognitive development. It has been learned that play can support schematization process of cognitive development. Further, it is understood that play is a tool in enriching cognitive progress can be made use from an early stage of development more specifically in infancy and early childhood. Play tool is useful not only for healthy children; that can be used as a therapeutic tool, and its efficacy has been proved its success.

\section{Facts observed regarding natural play in developing children}

At the first level the stage is characterized by simple reflexes, uncoordinated movements, and the first discrimination and recognition of human and nonhuman objects. This early stage starts from birth to 2 months: Play objects at this level of 
cognition merely strives to focus attention on an interesting object, to produce reactions that demonstrate recognition and provide experiences of reflexive grasp. 2 to 4 months: Play facilitating cognition at this level uses visual observation of stationary and moving objects, early sound play turn taking, reflexive holding of an object and moving it within the visual field. Mouthing of objects are preferred at this stage than handling with hands. 4 to 8 months: In this stage, intentional sensorimotor adaptation is dominated by the repetition of discovered patterns. Objects that produce a clear, direct response to the child's actions like percussion toys. The child grasps merely and handing objects from one hand to the other than releasing often until all objects within reach. 8 to 12 months: Play strategies from one toy are tried out on another toy. Simple combinations of objects are tried out such as banging a spoon on a plate and putting things out of containers. 12 to 18 months: In this stage, child play goes with experimentation and learns functional uses of one object on another. Play that includes putting in and taking out objects, transporting and matching the parts alike are suitable. 18 to 24 months: In this stage child start imitating others; here play involves modelling to explore objects. 2 to 4 years: Child appears with attitudes of animism, realism, and magical thinking are the characteristic behavior that gives a way to interactive games with increasingly complex shared rules.

This article is interconnecting some facts observed in the natural play of developing children in the various stages of Piaget's cognitive development. In recent years play therapy interventions have also been applied to infants and toddlers; the families who used play therapy as gained optimal benefits in early intervention of their children (Kelly-Zion et al., 2008). The cognitive development suggests that children move through four different stages of mental development in acquiring knowledge from the external environment. Further, leads to intellectual expansion and cognitive development. Piaget believed that children in the learning process are like little scientists - as they perform experiments and make observations as they interact with the environment; this is how they learn about the world. As kids interact with the world around them, they continually add new knowledge, build upon existing knowledge, and adapt to the previously held ideas and accommodate further information (Cherry, 2018).

In developmental stage children should provide with an opportunity to get exposed to rich and appropriate environmental stimuli thereby children can add these experiences in their mental schemas as they mature.

\section{Advantages and disadvantages of play method basing piglet's theory}

Usefulness: i. Piaget's work is recommended to all pediatric therapists, occupational therapist, cognitive behavioral therapists who find them frequently addressing cognitive development. ii. Provided with training teachers and parents can also facilitate cognitive development in children. iii. Play therapy can be used for normal children and children with neurodevelopmental problems. Limitation: i. Parents and teacher training is not available. ii. Lack of awareness. iii. Economic feasibility.

Here authors would like to propose some of the suitable plays that can be introduced to the parents as well as teachers.
In Paget's developmental stage theory of cognitive development, he suggested that learning of language is a part of cognitive development requires appropriate environmental stimuli and experiences as the child matures (Chapman and Routledge, 2005). Piaget's theory of cognitive development is one of the significant contributions to developmental psychology and education. It has a firm root in biology and epistemology. The epistemological concepts go with constructivism, adaptation, equilibration, abstraction. Genetic epistemology and genetic psychology were closely interrelated; it then briefly summarizes Piaget's theory of the development of intelligence focusing stages and factors of development (Anik, 2001). The Piagetian theory is the premier window on both infant cognitive development and plays development, the relationship between play and cognition is deeply interlaced for therapists. Using object play to facilitate cognition is based on the Piagetian stages found in the sensorimotor period that is birth to 2 years (Munier et al., 2008). Two critical processes involved in this learning process is the assimilation of new knowledge and expertise as they processed and accommodated these new experiences with existing internal organized patterns of thought and behavior that is known as schemas (Chapman and Routledge, 2005). Richer the learning experiences of children when they play against their environment better schematization occurs. Learning takes place through assimilation, i.e., organizing information and absorbing it into existing schema further accommodating new information's regarding objects or subjects when that cannot be assimilated into the existing schema. Indeed, schemata's get modified to include the object and subject as the children learn more, and it gets updated.

Further, this knowledge is stored as mental schemas as a reference, and more also, when they come across the similar experiences, this has been used in accommodating new ones and equilibrated the new and old schemas. The new knowledge from the experiences are assimilated and then adapted into existing schemata often updating those schemata with the unique experience with equilibration (Berger, 2014). The assembled schemas enrich child's cognition that makes them easy to interact with the world around them. Thus, this article spells that it is significant to update our schemas that can help people in their intellectual adaption. Indeed, it is virtuous to provide the children with richer play environment that can enrich their schematization process. Generally, in cognitive development in children create their own schemata for each of their experiences and the knowledge that gained from their environment. These updates are significant for the children for better adaption.

The teachers and parents can make use of play as a tool to support and enrich schematization process. The play as a tool can develop creatively by the parents having an understanding with given developmental model. However, assimilation and accommodation take its own time, during this period a child remains in each of these stage that is controlled by their personal cognitive development (Block, 1982) that can be stimulated with creative plays that communicated in the Table 1 introduced below. In the developmental process of children, as they learn to make sense of the world around them, they eventually pass through fourstages as the mind processes new information as they encounter them (Piaget, 1952). Piaget posited that children progress through these four stages that universally seen all the children under 
development (Piaget, 1959). Understanding and conceptualization of stages of development, learning aspects related to development and guidelines for the teachers and parents to enrich the schemas that teachers and parents to build the most suitable 'play' for children through interactional play with the environment are listed in Table 1.

It has been learned that play is fundamental to cognitive development. In Piagetian four stages and their respective substages of 'play' has been proved to be helping tool in child's cognitive development. Thus, understanding what actions, they can take in different situations, the effects of their actions, whether those actions are right for the circumstance. Children commonly grow with interactional play with their environment. This play has a significant impact on their cognitive development. The very basis of the theory of play in cognitive development is that the child developmental progress in each of the stages depends upon getting the appropriate environmental stimuli at the right time. This helps them to develop meaningful mental schemas of their environment. Thus, the stages of cognitive development can guide teachers and parents to build the most suitable 'play' for children at each stage and sub-stage so that can help them to progress to the next (Burgemeester). Children learn their environment naturally; in young children play is a part of their learning. Preschoolers more into playing that go with hand in hand with their learning process, in fact, their brains are hard at work putting together vital knowledge about the world and support preschoolers' cognitive development (Raising Children Network, 2018). Preschool children commonly engage in a lot of pretend play is observed more in middle-class modern societies this fact has been widely conceptualized by teachers and parents. Though game often has distinctly seen as a socializing tool in children; indeed, it also builds distinctly cognitive skills in them and creates a bridge between the social world and the more individualistic world of cognitive abilities (Lillard, 2002; Saracho and Spodek, 2003; Sutton-Smith, 1997).

Table 1: Guidelines for Teachers and Parents in Enriching Schematization through the Steps of Cognitive Development.

\begin{tabular}{|c|c|c|c|c|}
\hline Stages of cognitive development & $\begin{array}{c}\text { Learning that takes place at each } \\
\text { stage }\end{array}$ & $\begin{array}{l}\text { How learning takes place at each } \\
\text { stage of cognitive development }\end{array}$ & $\begin{array}{c}\text { Interactional play with } \\
\text { the environment should be } \\
\text { enriched through }\end{array}$ & $\begin{array}{l}\text { Creative ways to explore } \\
\text { plays in enriching cognition }\end{array}$ \\
\hline $\begin{array}{c}\text { Sensorimotor stage (Birth to } 2 \\
\text { years) }\end{array}$ & $\begin{array}{l}\text { The infant builds an understanding } \\
\text { of himself/herself and reality through } \\
\text { interactions with the environment. } \\
\text { Learns to differentiate between self } \\
\text { and other objects. }\end{array}$ & $\begin{array}{l}\text { Learning takes place through the orga- } \\
\text { nization of information and absorbing it } \\
\text { into existing schema \& accommodating } \\
\text { when an object cannot be assimilated in } \\
\text { the schemata. }\end{array}$ & $\begin{array}{l}\text { Child's experiences of sensory } \\
\text { stimulations }\end{array}$ & $\begin{array}{l}\text { Take any infant behavior such } \\
\text { as feeding, urinating, excret- } \\
\text { ing can be disciplined by } \\
\text { conditioning infant through } \\
\text { interlinking sensation with } \\
\text { behaviors }\end{array}$ \\
\hline Preoperational stage (ages 2 to 4 ) & $\begin{array}{c}\text { The child is not yet able to concep- } \\
\text { tualize abstractly and needs concrete } \\
\text { physical situations. }\end{array}$ & $\begin{array}{l}\text { Objects are classified in simple ways, } \\
\text { primarily by essential features. }\end{array}$ & $\begin{array}{l}\text { Organizing play that has a } \\
\text { feature of simple classifying } \\
\text { nature of objects and subjects. }\end{array}$ & $\begin{array}{l}\text { Provide rich intellectual } \\
\text { environment. So that they can } \\
\text { form enriched schemas }\end{array}$ \\
\hline $\begin{array}{c}\text { Concrete operations (ages } 7 \\
\text { to } 11 \text { ) }\end{array}$ & $\begin{array}{c}\text { The child's physical experience } \\
\text { accumulates, and accommodation is } \\
\text { increased. }\end{array}$ & $\begin{array}{l}\text { Make rational/logical judgments basing } \\
\text { concrete objects from their environment }\end{array}$ & $\begin{array}{l}\text { Provision made to sensible } \\
\text { and reasonable base in their } \\
\text { interaction }\end{array}$ & $\begin{array}{l}\text { Provide observable and } \\
\text { demonstrable objectivity for } \\
\text { their task in their external } \\
\text { world }\end{array}$ \\
\hline Formal operations (ages 11 to 15 ) & $\begin{array}{l}\text { The child's cognition reaches its final } \\
\text { form. }\end{array}$ & $\begin{array}{l}\text { Think abstractly very similar to an adult } \\
\text { now capable of deductive and hypothet- } \\
\text { ical reasoning }\end{array}$ & $\begin{array}{l}\text { Treating him/her as an adult } \\
\text { allowing them to decide using } \\
\text { their own abstraction and } \\
\text { counterfactual thinking }\end{array}$ & $\begin{array}{l}\text { After age eleven enable the } \\
\text { children to take their own de- } \\
\text { cisions give only suggestions } \\
\text { as a guideline. }\end{array}$ \\
\hline
\end{tabular}

This is the table to communicate the various information insight drown on observing children in their cognitive developmental stages introduced by Piaget.

It is significant to know about facts related to cognitive development in children that have an association with their process of making sense of the world around them and eventually pass through four-stages in which the mind processes with the new information encountered as the children move through these stages (Piaget, 1976).

\section{CONCLUSION}

This article summarizes new ways of creating a naturalistic play that can facilitate cognitive development. Introducing age-related play in developing children by the teachers and parents can enrich the metal schemas in children; the information to create age-related play has been summarized in the above table as a guide for play creation. This concept implies both normal and children with neurodevelopmental issues. Thus, understanding the implication of play work and developing self-play tools is useful in enhancing schematization signifies its' usefulness for professionals, teachers, and parents who can promote cognitive skills in developing children. This type of play can be created individually suitable to the environmental situations basing developmental pattern. Further, it can also bring the better success in therapeutic interventions. The implication of this short communication can pave the way for mental healthiness in budding children.

\section{CONFLICT OF INTEREST}

Authors posses no conflict of Interest.

\section{FINANCIAL SUPPORT}

This work does not obtain any financial support from any source.

\section{REFERENCES}

Anik DeR. 2001. Piaget's theory of child development. In: Smelser NJ, Baltes PB Eds. International Encyclopedia of the Social and Behavioral Sciences. Pergamum: Oxford. 11434-11437. Available at https:// archive-ouverte.unige.ch/unige:6801 [Accessed June 22, 2018].

Berger KS. 2014. The developing person through the lifespan. $9^{\text {th }}$ Edition, 119 Hazelwood Road, Duffield DE56 4AA, UK: Worth Publishers. 
Block J. Assimilation, accommodation, and the dynamics of personality development. Child Dev 1982; 53(2):281-295.

Burgemeester A. Jean Piaget's Theory of Play. Psychologized Psychology Everywhere. Available at https://www.psychologized.org/jeanpiagets-theory-of-play/ [Accessed on March 10, 2018].

Chapman S, Routledge C. 2005. Key Thinkers in Linguistics and the Philosophy of Language. First Edition, New York, USA: Oxford University Press.

Cherry K. Piaget's Theory: The 4 Stages of Cognitive Development Background and Key Concepts of Piaget's Theory. 2018. Available at https://www.verywellmind.com/piagets-stages-of-cognitivedevelopment-2795457 [Available May 8, 2018].

Gruber HE, Voneche JJ. 1995. The Essential Piaget: An Interpretive Reference and Guide. 100th Anniversary Edition. 230 Livingston Street, Northvale, NJ 07647, USA: Jason Aronson, Inc.

Kelly-Zion S, Schaefer CE, McCormick J, Akiko Ohnogi (Eds). 2008. Play therapy for very young children. Lanham, Maryland, USA: The Rowman \& Littlefield Publishers, Inc.

Lillard A. 2002. Pretend play and cognitive development. In: Goswami U (Ed.), Blackwell Handbook of childhood cognitive development. Oxford, UK: Blackwell, 188-205.

McLeod S. Jean Piaget's Theory of Cognitive Development. Developmental Psychology. Simply Psychology. 2018. Available at https://www.simplypsychology.org/simplypsychology.org-Jean-Piaget.pdf [Accessed July 2, 2018].

Munier V, Myers CT, Pierce D. 2008. 7 - Power of Object Play for Infants and Toddlers. Play in Occupational Therapy for Children. $2^{\text {nd }}$
Edition, 219-249. https://doi.org/10.1016/B978-032302954-4.10007-8 [Accessed June 22-2018].

Piaget J. 1952. The origins of intelligence in children. New York, USA: International Universities Press. Available at http://www.pitt. edu/ strauss/origins r.pdf [March 10, 2018].

Piaget J. 1959. The language and thought of the child. $3^{\text {rd }}$ Edition, 11 New Fetter Lane, London, UK: Routledge \& Kegan Paul Ltd.

Piaget J. 1976. Piaget's Theory. In: Inhelder B, Chipman HH, Zwingmann C (Eds). Piaget and His School A Reader in Developmental Psychology. Springer Study Edition. Berlin, Heidelberg: Springer, 11-23.

Raising Children Network (Australia) Limited. 2018. Thinking and play: preschoolers. Raising Children Network. Available at http://raisingchildren.net.au/articles/school_age_play_and_cognitive_ development.html [Accessed on March 10, 2018].

Saracho O, Spodek B (Eds.). 2003. Contemporary perspectives on in early childhood education. Greenwich, CT: Information Age Publishers.

Sutton-Smith B. 1997. The ambiguity of play. Cambridge, MA: Harvard University Press.

How to cite this article:

Bhagat V, Haque M, Jaalam K. Enrich Schematization in Children: Play as The Tool for Cognitive Development. J App Pharm Sci, 2018; 8(07): 128-131. 